\title{
Tax Evasion, Tax Morale, and Trade Regulations: Company-Level Evidence from Poland
}

\author{
Dagmara Nikulin
}

\begin{abstract}
A B S T R A C T
Objective: To investigate the determinants of the phenomenon of evading taxes among polish entrepreneurs. In particular, I examine such factors as tax administration satisfaction, tax morale, tax burden, and the influence of trade regulations.

Research Design \& Methods: A survey study conducted in 2017 in Poland among 454 enterprises. I used the zero-inflated negative binomial modelling technique to examine the impact of factors on the probability and extent of tax evasion. I also checked the robustness of the obtained results.
\end{abstract}

Findings: I report low tax morale of company managers, low level of satisfaction of tax administration, and tightness of trade regulations as important factors that impact the probability of tax evasion. Moreover, tax morale plays an important role in explaining the extent of underreporting income. I report no significant impact of tax burden on the probability to evade taxes and the magnitude of evasion.

Implications \& Recommendations: Tax burden should not be considered as predominant in explaining tax evasion inclinations. More social aspects, like the perceived quality of governance, the level of trade regulations, and tax morale, become increasingly important in affecting tax evasion attitudes.

Contribution \& Value Added: I offer empirical evidence on the determinants of tax evasion. To that end, I utilise a new econometric approach and own primary data.

\begin{tabular}{llll}
\hline $\begin{array}{l}\text { Article type: } \\
\text { Keywords: }\end{array}$ & $\begin{array}{l}\text { research article } \\
\text { shadow economy; microdata; tax compliance }\end{array}$ \\
JEL codes: & H26, O17 & & \\
\hline \multicolumn{2}{l}{ Received: 20 November 2019} & Revised: 31 January 2020 & Accepted: 3 February 2020 \\
\hline
\end{tabular}

Suggested citation:

Nikulin, D. (2020). Tax Evasion, Tax Morale, and Trade Regulations: Company-Level Evidence from Poland. Entrepreneurial Business and Economics Review, 8(1), 111-125. https://doi.org/10.15678/EBER.2020.080106 


\section{INTRODUCTION}

Reducing tax evasion level is a complex matter as several approaches combating the shadow side of the economy may be applied. The related literature proposes plenty theoretical and empirical considerations on the causes and policy measures regarding tax evasion (for a review, see Buehn \& Schneider, 2012). The most prevalent policy measures mainly cover higher penalties and an increase in the frequency of audits. As the traditional model proposed by Allingham and Sandmo (1972) asserts, the decision on evading taxes depends on the calculation between profits from tax evasion, on the one hand, and the risk of detection on the other hand. Today, the traditional model suffers criticism because of its simplicity and other dimensions like institutions, individual characteristics, morale, ethics, culture, and social stigma, which should be included when explaining tax evasion (Abdixhiku, Krasniqi, Pugh, \& Hashi, 2017). As Torgler and Schneider argue, it is really important to investigate not only objective factors of tax evasion like tax burden, rate of public expenditure, or regulation density but also subjective factors like the perceptions, attitudes, and motivations reflected in tax morale or (perceived) institutional quality (Torgler \& Schneider, 2009).

Some postulate that - apart from simple tax rate reduction - policy-makers should seek an alternative policy that may be more successful in fighting tax evasion problems (Enste, 2010). Many studies try to investigate the possible causes of taxpayers' behaviour to describe tax evasion determinants and formulate policy implications. Apart from tax burden (Abdixhiku et al., 2017; Joulfaian, 2009; Nur-Tegin, 2008), many others causes for the development of tax evasion appear in the literature, like tax morale (Alm, 2012; Alm \& Torgler, 2006; Cummings, Martinez-Vazquez, McKee, \& Torgler, 2009), the quality of governance (Hanousek \& Palda, 2004; Torgler \& Schneider, 2007), and the tightness of regulations (Enste, 2010; Schneider, 2014).

However, despite the existing evidence on determinants of tax evasion, there still is space for further research, especially for those who analyse the social dimension of this phenomenon (Abdixhiku et al., 2017). A review of tax evasion theories by Slemrod (2007) suggests that - despite deterrence being a powerful factor in evasion decisions - there is still a need for further research on tax evasion determinants. In this study, I aim to test contemporary hypotheses on the causes of tax evasion behaviour. To do this, I use the results from a survey conducted among Polish entrepreneurs in 2017, which covered 454 effective interviews. I use the zero-inflated negative binomial modelling technique to examine not only the determinants of the decision to evade taxes but also to find factors that increase the probability of evading. I contribute to the existing literature by providing - to the best of our knowledge - the first empirical evidence on tax evasion determinants in Poland based on microdata. A good reference point is the research of Abdixhiku et al. (2017) who examine the determinants of tax evasion in 26 transition countries, including Poland. The study is based on firm-level company data derived from WB/EBRD Business Environment and Enterprise Performance Survey (BEEPS) for 2002 and 2005, covering 12,692 firms. The joint results obtained for all 26 transition countries indicate the possible reasons for tax evasion behaviour: tax burden, low trust in the government and the judicial system, high perceptions of corruption, and high compliance costs. Moreover, the results of my study may 
be useful for other countries - especially from Central and Eastern Europe - in creating policy measures to tackle this phenomenon.

This article begins with a discussion on the driving forces of the shadow economy and tax evasion based on the existing literature. I focus on the influence of tax morale, institutional quality, tax burden, and state regulations on tax evasion behaviour. Section 3 includes a description of the data and methodology applied. In section 4, I present the estimations of our results and provide relevant discussion. Section 5 concludes the study.

\section{LITERATURE REVIEW}

\section{Shadow Economy and Tax Evasion: Driving Forces}

There are many factors that affect the probability to evade taxes. The literature offers plenty of research both on tax evasion and tax compliance determinants. In general, two main groups of reasons may be distinguished. The first approach, based on the rational choice model, includes an economic assumption that the decision on evading taxes depends on the individual perceptions between gains and the risk of detection and punishment (Allingham \& Sandmo, 1972). This popular approach asserts that the probability of detection and punishment may influence tax evasion behaviour. Among other economic factors, the burden of taxation is the most quoted determinant of tax compliance. However, the empirical evidence on the influence of tax rate on tax evasion is rather inconclusive (Bernasconi, Corazzini, \& Seri, 2014). Even studies based on the same data show different results, depending on the selected set of variables; compare the research based on Business Environment and Enterprise Performance Survey (BEEPS) from Nur-Tegin (2008) and Joulfaian (2009).

Another area of study is related to the correlation between the quality of institutions and the size of shadow economies, therefore also tax evasion inclination. Torgler and Schneider (2007) conduct a cross-country analysis based on panel study and find that institutional quality is a significant factor that impacts the size of the shadow economy. Hanousek and Palda (2004) analyse citizen perceptions of the quality of government services as the determinant of tax evasion. Based on the survey conducted in the Czech and Slovak Republics, Hungary, and Poland, they find strong evidence on the correlation between tax avoidance and the quality of government services. Barone and Mocetti (2011) use individual Italian data to claim a positive relationship between the efficiency of spending public money and the attitude towards paying taxes.

Apart from institutional quality and governance, the level of liberalisation measured by the tightness of regulations may play a role in explaining attitudes towards tax evasion (Enste, 2010; Schneider, 2014). If existing regulations are tighter, including the trade regulations, then there is a greater possibility of underreporting to circumvent stricter rules.

Another strand of literature exceeds the traditional deterrence model and takes into account non-economic factors like cultural values, tax morale, social and ethical norms to explain tax evasion (Cummings et al., 2009). A comprehensive review of current studies on tax evasion that focuses on behavioural aspects is presented by Pickhardt and Prinz (2014). Wenzel (2004) argues for a significant difference between the impact of personal norms (individual morale of taxpayers) and social norms (morale attributed to other taxpayers) on tax compliance. While the relationship between personal norms and 
tax compliance is positive and strong, the influence of social norms depends on the level of group identification. Based on the self-categorisation theory, Wenzel finds that social norms influence taxpayers' behaviour only if group identification is strong. Otherwise, social norms play no role in tax compliance (Wenzel, 2004). A cross-country study conducted by Bobek, Roberts, and Sweeney (2007) reveals that - among the most influential factors - personal moral norms and norms attributed to people close to them play an important role in creating taxpayers' behaviour. Results presented by Ferrer-i-Carbonell and Gërxhani (2016) indicate that tax evasion in Central and Eastern Europe countries is also negatively associated with individuals' life satisfaction. The study conducted by McGee and Benk (2011) reveals that tax evasion behaviour is related to government oppressiveness and corruption. The stronger the perceived unfairness of the system, the higher the inclination to evade taxes. Moreover, in another study, Mcgee and Benk (2019) find that tax evasion is smaller if tax rates are low, and people feel that they receive good value for their taxes. Turning towards socio-demographic determinants, the survey conducted by James, Mcgee, Benk, and Budak (2019) among English students and university members shows that young, non-married, and less-educated men are less opposed to evading taxes if they have such chance.

Besides studies that analyse the influence of social norms on tax evasion, another vein of research explains the correlation between tax morale impact and the size of the shadow economy (among others, Alm, Martinez-Vazque, \& Torgler, 2006; Alm \& Torgler, 2006; Torgler, 2005; Torgler \& Schneider, 2009). Indeed, tax morale may be defined as intrinsic motivation to pay taxes (Torgler \& Schneider, 2007) or as "a belief in contributing to society by paying taxes" (Torgler \& Schneider, 2009, p. 230). Interestingly, Buehn and Schneider (2012) claim that tax morale is influenced by several factors like deterrence and the quality of state institutions. Doerrenberg and Peichl (2013) link tax morale to the progressivity of taxes and argue that progressive taxes have a positive impact on tax morale. Russo (2013) claims the positive relationship between tax morale, social capital, political participation, and immigration but a negative relationship between tax morale, the dissatisfaction with public services, and the level of unemployment. Similarly, Alm and Gomez (2008) find an important role of social capital in creating tax morale in Spain. Tax morale rises along with the perception of benefits in the form of public goods and services. The majority of the literature shows a negative correlation between personal ethical attitudes and tax evasion behaviour (see, among others, Kaplan, Newberry, \& Reckers, 1997; Kogler, Batrancea, Nichita, Pantya, Belianin, \& Kirchler, 2013; van Dijke \& Verboon, 2010).

Based on the above-presented literature review, I develop the following hypotheses in this article:

H1: There is a negative relationship between tax morale presented by entrepreneurs and the inclination to evade taxes.

H2: The tightness of regulation, including trade regulation, boosts the probability of tax evasion.

H3: The overall satisfaction related to the quality of governance, measured by satisfaction with tax administration, will enhance tax compliance. 


\section{MATERIAL AND METHODS}

\section{Sample and Questionnaire}

To test tax evasion hypotheses indicated in the previous section, I use quantitative data derived from a survey study conducted among Polish companies in April 2017. The questionnaire is proposed by Putniňs and Sauka (2015) who have been conducting business survey studies related to the shadow economy in the Baltic countries since 2010. My survey consists of 23 questions related to external influences, government policy, the amount of informal business, company performance, attitudes towards informal economy, and barriers to running a business. The survey sample covers 454 companies in Poland and is representative of Polish enterprises. For the purpose of representativeness, a random stratified sample is used with the following strata: region (voivodeship), industry, and employment size. The survey study was conducted by a data-collecting company and provides phone interviews with top managers or company owners in Poland. A description of the sample is presented in the Appendix, part A.

In reference to the aim of this article, I intend to gauge the probability of being engaged in the shadow economy, in particular to evade taxes. I use a direct approach to measure tax evasion in Poland based on a company survey. Given the data availability and the conventions used in the literature, I define tax evasion variable as the extent of the underreporting of business income. Keeping in mind the sensitive nature of the surveyed topic and the possible reluctance of respondents to giving truthful answers, I applied an indirect way of asking. Proposed and applied by Putninšs and Sauka (2015) and discussed in Gërxhani (2007), this indirect approach is particularly is based on questions to company managers but in reference to their opinion about firms in their industry instead of their own company. Past evidence on tax evasion claims that perceived tax evasion in the reference group is correlated with self-reported tax behaviour (Webley, Cole, \& Eidjar, 2001), so this indirect indication may be used instead of the respondent's own answer (Gërxhani, 2007). Due to the difficulties related to the direct way of asking, I measured how company owners and managers perceive the scale of income underreporting in firms in their industry. Then, I used the assessed extent of income underreporting in the industry as a proxy for tax evasion prevalence in the interviewed company. In the remaining part of the article, the term tax evasion refers to this assumption. A detailed question wording is presented in Appendix B.

Table 1 presents the descriptive statistics of the variables used. As reported, the extent of underreporting of business income among Polish entrepreneurs is considerable. However, $30 \%$ of respondents declare no underreporting of income by firms in their industry, the remaining $70 \%$ of them claim some extent of tax evasion, among them over $50 \%$ state that the degree of underreporting is greater than $10 \%$. In order to avoid the distortion of the results, I replace the extreme values by certain percentiles. In particular, the values below the 1st and above the 99th percentile are replaced by the values at 1st and 99th percentiles, accordingly.

To seek out the determinants of tax evasion, I considered a set of determinants, which correspond to the hypotheses indicated in the previous section. In particular, I employed the explanatory variables related to tax morale hypothesis (justified_to_cheat), regulation hypothesis (obstacle_trade), and governance quality hypothesis (tax_administration_sat). A detailed description of these variables is presented in 
Appendix B. Moreover, aware of the rich body of potential factors that influence the inclination to evade taxes, I included control variables in our regressions, like the perceived tax burden (obstacle tax_rates) and the company size (no_employees).

Table 1. Descriptive statistics of dependent and explanatory variables

\begin{tabular}{|l|l|l|l|l|l|}
\hline \multicolumn{1}{|c|}{ Variable name } & \multicolumn{1}{c|}{ N } & \multicolumn{1}{c|}{ Mean } & \multicolumn{1}{c|}{ Sd } & \multicolumn{1}{c|}{ Max } & \multicolumn{1}{c|}{ Min } \\
\hline underreport_income & 454 & 14.51101 & 13.75563 & 0 & 80 \\
\hline justified_to_cheat & 454 & 2.367841 & 0.6604074 & 1 & 4 \\
\hline obstacle_trade & 454 & 2.251101 & 1.2354 & 0 & 4 \\
\hline tax_administration_sat & 454 & 2.810573 & 0.7885903 & 1 & 5 \\
\hline obstacle_tax_rates & 454 & 3.070485 & 0.7687961 & 0 & 4 \\
\hline no_employees & 454 & 1.539648 & 0.7044268 & 1 & 7 \\
\hline
\end{tabular}

Source: own elaboration based on company survey study.

\section{Modelling Method}

As I aimed to investigate the relationship between tax evasion and possible determinants, I employed the econometric modelling technique in the empirical part. The selected estimation method depended on the description of the dependent variable. Keeping in mind that a significant part of observations of the dependent variable equals zero $-30 \%$ of respondents claims no underreporting of income in the firms in their industry - I used zero inflated negative binomial regression, which is proper for attributes of this variable. The zero-inflated negative binomial regression was used for count data with excessive zeros and consists of two parts: the first one is the count model (negative binomial model) and the second one is binary outcome model predicting the excessive zeros. In our case, I reported two parts of the model: the first one describes the influence of selected determinants on the extent of tax evasion (count model), while the second part reports which factors impact the probability to evade taxes (logit model). In the second part (logit model) I analysed factors which enhance the probability of being zero (no tax evasion). Utilisation of this model has an additional advantage: it allowed me to analyse not only the determinants that enhance the inclination to tax evasion but also to indicate the factors that impact the attitudes of current tax evaders.

\section{RESULTS AND DISCUSSION}

The Results

The results of regression estimation are reported in Table 2. I present the results separately for the negative binomial count model (upper part of Table 2) and the zero-inflated model (lower part). I used the same regressors in both models.

Firstly, I interpret the second part of the model by predicting whether a company underreports business income or not. In other words, I assess the probability that the dependent variable equals zero, what in our case means no tax evasion. I can see that the propensity of companies to underreport is greater if the tax morale of company owner/manager is lower. If the respondents are more inclined to justify cheating on taxes, the probability of underreporting of business income is greater. In other words, the probability of no underreporting is lower. As the variable justified_to_cheat - that reflects the 
company managers' attitudes towards tax evasion - is statistically significant, we can confirm the assumption on the positive influence of attitude factors on tax compliance.

Table 2. Estimations results: the impact of tax evasion determinants

\begin{tabular}{|c|c|c|c|}
\hline \multirow{2}{*}{ Dependent variable } & \multicolumn{3}{|c|}{ degree of underreporting business income (in \%) } \\
\hline & (1) & (2) & (3) \\
\hline \multicolumn{4}{|c|}{ Negative binomial count model } \\
\hline \multirow[t]{2}{*}{ justified_to_cheat } & $0.119 *$ & $0.110^{*}$ & $0.109^{*}$ \\
\hline & {$[0.064]$} & {$[0.061]$} & [0.061] \\
\hline \multirow[t]{2}{*}{ obstacle_trade } & 0.003 & 0.005 & 0.005 \\
\hline & {$[0.032]$} & {$[0.032]$} & {$[0.032]$} \\
\hline \multirow[t]{2}{*}{ tax_administration_sat } & 0.005 & 0.006 & 0.006 \\
\hline & {$[0.053]$} & {$[0.052]$} & {$[0.052]$} \\
\hline \multirow[t]{2}{*}{ obstacle_tax_rates } & -0.010 & -0.010 & - \\
\hline & {$[0.045]$} & {$[0.045]$} & - \\
\hline \multirow[t]{2}{*}{ no_employees } & 0.033 & - & - \\
\hline & [0.047] & - & - \\
\hline \multicolumn{4}{|c|}{ Zero inflated model } \\
\hline \multirow[t]{2}{*}{ justified_to_cheat } & $-0.805^{* * *}$ & $-0.760 * * *$ & $-0.764 * * *$ \\
\hline & {$[0.199]$} & {$[0.193]$} & {$[0.193]$} \\
\hline \multirow[t]{2}{*}{ obstacle_trade } & $-0.197 * *$ & $-0.208 * *$ & $-0.210 * *$ \\
\hline & [0.099] & [0.098] & {$[0.098]$} \\
\hline \multirow[t]{2}{*}{ tax_administration_sat } & $0.289 * *$ & $0.289 * *$ & $0.288^{* *}$ \\
\hline & {$[0.142]$} & {$[0.142]$} & {$[0.142]$} \\
\hline \multirow[t]{2}{*}{ obstacle_tax_rates } & -0.063 & -0.067 & - \\
\hline & [0.139] & {$[0.140]$} & - \\
\hline \multirow[t]{2}{*}{ no_employees } & -0.186 & - & - \\
\hline & {$[0.184]$} & - & - \\
\hline II & -1413.83 & -1414.76 & -1414.91 \\
\hline $\mathrm{N}$ & 454.00 & 454.00 & 454.00 \\
\hline N_zero & 138.00 & 138.00 & 138.00 \\
\hline
\end{tabular}

Notes: Zero-inflated negative binomial regression with robust standard errors; standard errors in parentheses; sector dummies included but not reported; variable description as in Appendix $B$; ${ }^{*} p<0.10,{ }^{* *} p<0.05,{ }^{* * *} p<0.01$. Source: own elaboration based on company survey study.

These results agree with previous evidence (Kaplan, Newberry, \& Reckers, 1997; Kogler et al., 2013; van Dijke \& Verboon, 2010). Moreover, I see that the propensity of companies to underreport their income is higher if the managers perceive trade regulations as a very severe obstacle. If trade regulations are tighter, then the company has a greater incentive to underreport a part of their income. In this way, I confirm the assumption proposed by Enste (2010) and Schneider (2014). Going further, I find that the phenomenon of tax evasion is less prevalent in companies in which managers indicate a high level of satisfaction with the quality of tax administration. In this way, I support the hypothesis about the positive impact of institutional quality on tax compliance. Similar outcomes are presented in the study from Hanousek and Palda (2004) and Torgler and Schneider (2007). Interestingly, my results reveal that the decision to evade taxes does not depend on tax burden. There is no statistically significant impact of the perceived obstacle in the form of tax rates on 
the probability to underreport income. Similarly, I find no relationship between the inclination to tax evasion and the size of the enterprise.

Secondly, based on the results from the negative binomial count model (the upper part of Table 2) I can assess which determinants impact the extent of underreporting of business income for those who already evade taxes. In other words, I can examine whether the same factors that determine the decision to evade or not are still significant if we consider only those enterprises which underreport a part of their income. In short, the indication is that only the tax morale of company managers may influence the extent of underreporting income. If the tax morale of company managers is lower, then, other things being equal, the degree of tax evasion is higher. Interestingly, another possible factor does not contribute to the scope of underreported income.

\section{Sensitivity Analysis}

To check the reliability of my results, I ran several additional regression as a robustness check. Table 3 present the results of the sensitivity analysis.

Table 3. Odds ratios of determinants of tax evasion

\begin{tabular}{|l|l|l|l|}
\hline \multirow{2}{*}{ Dependent variable } & \multicolumn{2}{c|}{ The degree of underreporting business income (intervals) } \\
\cline { 2 - 4 } & \multicolumn{1}{|c|}{$(\mathbf{1})$} & \multicolumn{1}{c|}{ (2) } & \multicolumn{1}{c|}{ (3) } \\
\hline justified_to_cheat & $2.418^{* * *}$ & $2.418^{* * *}$ & $2.499^{* * *}$ \\
\hline & {$[0.508]$} & {$[0.606]$} & {$[0.535]$} \\
\hline obstacle_trade & $1.238^{*}$ & $1.238^{*}$ & 1.165 \\
\hline & {$[0.110]$} & {$[0.130]$} & {$[0.0987]$} \\
\hline tax_administration_sat & $0.761^{*}$ & $0.761^{*}$ & $0.744^{*}$ \\
\hline & {$[0.0978]$} & {$[0.1000]$} & {$[0.0946]$} \\
\hline obstacle_tax_rates & 1.030 & 1.030 & 1.032 \\
\hline & {$[0.122]$} & {$[0.173]$} & {$[0.123]$} \\
\hline no_employees & 1.317 & 1.317 & 1.192 \\
\hline & {$[0.225]$} & {$[0.247]$} & {$[0.191]$} \\
\hline sector dummies & & & yes \\
\hline $\mathrm{N}$ & 454 & 454 & 454 \\
\hline Wald chi ${ }^{2}$ & 54.89 & 117.88 & 50.12 \\
\hline Prob>chi & & 0.00 & 0.00 \\
\hline Pseudo $\mathrm{R}^{2}$ & 0.00 & 0.0679 & 0.0598 \\
\hline
\end{tabular}

Notes: ordered logistic regression; standard errors in parentheses; specifications (1) and (2) with robust standard errors, specification (3) with robust cluster errors clustered at province level (NUTS 2); sector dummies not reported; variables' categories as in Appendix $\mathrm{B} ;{ }^{*} \mathrm{p} \leq 0.10,{ }^{*} \mathrm{p} \leq 0.05,{ }^{* * *} \mathrm{p} \leq .01$.

Source: own elaboration based on the company survey study.

I utilized an ordered logistic regression with robust standard errors, as my outcome variable was recoded into the intervals: 1 for no underreporting at all, 2 for underreporting between $1-10 \%$ of business income, 3 for $11-30 \%$, 4 for $31-50 \%, 5$ for $51-75 \%, 6$ for $76-100 \%$, accordingly. The results presented in Table 3 confirm my baseline findings: the propensity for greater tax evasion rises along with lower tax morale, lower satisfaction with tax administration, and greater obstacles related to trade regulations. Again, I find no support for the notion that greater involvement in tax evasion stems from a higher tax burden. 


\section{DISCUSSION}

Based on the above presented results, I can verify the hypotheses presented in Section 2. Regarding hypothesis $\mathrm{H} 1$ related to the impact of tax morale on tax behaviour, I find that moral aspects play an important role both in the decision to evade taxes and on the extent of this evasion. Therefore, I can fully confirm hypothesis $\mathrm{H} 1$. This reading follows the literature, which holds that the moral attitudes of taxpayers determine their behaviour towards tax evasion (Torgler \& Schneider, 2009). Furthermore, I test the assumption about the impact of trade regulations on the inclination to evade taxes. In this case, my results reveal that tight trade regulations may enhance the inclination to evade taxes, but these are not significant enough to explain the level of this evasion. Hence, trade regulations do not determine the extent of income underreporting. As I predominantly sought to test whether the tightness of regulation determines the probability of tax evasion, I can now fully confirm hypothesis $\mathrm{H} 2$. Therefore, I contribute to the existing evidence provided by Schneider (2014). Finally, I examine the relationship between perceived institutional quality and inclination to cheat on taxes. Again, I find that the satisfaction with tax administration may influence the inclination to tax evasion, not the extent of this phenomenon. Therefore, I can confirm hypothesis 3 , which asserts that the overall satisfaction related to the quality of governance enhances tax compliance. This finding agrees with the previous evidence presented in the literature (Hanousek \& Palda, 2004; Torgler \& Schneider, 2007). Based on a similar survey conducted in Baltic states in 2014, Putniň and Sauka's study (2015) finds several shadow economy determinants against this background, such as tolerance towards tax evasion, satisfaction with state revenue services, the government's tax policy, business legislation, and the government's support for entrepreneurs. My study contributes to these findings by providing evidence from Poland.

\section{CONCLUSIONS}

The literature agrees that the phenomenon of tax evasion is extremely important and requires further exploration, as it results in reduced revenues to state budgets, unfair competition, and a disrupted system of public funds redistribution. As the problem of hidden economy concerns all countries, the explanation of the reasons for tax evasion and shadow economy activities gains in importance. In this article, I consider the determinants of tax evasion, including tax morale, trade regulation, and related institutional quality. To do this, I employed a company-level survey conducted among Polish entrepreneurs. I used the perceived degree of underreporting of business income in industry firms as the indication of tax evasion measures. Among the explanatory variables, I included determinants that reflect our three hypotheses, which evaluate the relationship between tax evasion and tax morale presented by entrepreneurs, the tightness of trade regulations, and the overall satisfaction with tax administration. As a control variable, I added the perceived severity of tax burden and company size.

Our results show that the higher the subjective permission to avoid taxes (tax morale), the higher the underreporting inclination. Other factors that increase the probability to evade taxes include the tightness of perceived trade regulations and a low level 
of satisfaction with the quality of tax administrations. With regards to the above-mentioned determinants, the influence on tax evasion is of the expected sign and confirms previous evidence from the literature. Furthermore, I report no significant impact of tax burden, often postulated in the literature. Interestingly, I exceed measures that seek to describe the probability of tax evasion and provide evidence on the factors that impact the extent of this phenomenon. In particular, I find that for those who already evade taxes, tax morale may affect the extent of the underreporting.

The main contribution of this article is twofold. Firstly, I provide empirical evidence on tax evasion determinants based on the company-level survey, which fills the existing gap on tax evasion and shadow economy studies, especially in Poland. My findings show a good consideration of the possible causes of tax evasion. Secondly, I address methodological issues raised by tax evasion determinants analysis by adopting the zero-inflated negative binomial model, which allows for the determination of factors that influence not only tax evasion inclination but also the extent of this evasion. This brings important contributions from both the scientific and political perspective.

Despite the significant contribution, this article shows several limitations. As the analysed phenomenon is of very sensitive nature, my results may be distorted because of untruthful answers. Moreover, in most of the questions asked in the survey, an indirect way of asking was applied. However, I based my approach on the method available in the literature, so some readers may understand tax evasion measure as a perceived extent of underreporting. Finally, in view of the relatively small sample of Polish enterprises, my research should be considered as preliminary. Moreover, I aim to initiate further research on tax evasion in Poland, in particular on its sources and possible relevant solutions. My findings can contribute to the debate on the tax evasion phenomenon in Poland and other European countries.

\section{REFERENCES}

Abdixhiku, L., Krasniqi, B., Pugh, G., \& Hashi, I. (2017). Firm-level determinants of tax evasion in transition economies. Economic Systems, 41(3), 354-366. https://doi.org/10.1016/j.ecosys.2016.12.004

Allingham, M.G., \& Sandmo, A. (1972). Income tax evasion: a theoretical analysis. Journal of Public Economics, 1(3-4), 323-338. https://doi.org/10.1016/0047-2727(72)90010-2

Alm, J., \& Gomez, J.L. (2008). Social Capital and Tax Morale in Spain. Economic Analysis and Policy, 38(1), 73-88.

Alm, J., Martinez-Vazque, J., \& Torgler, B. (2006). Russian attitudes toward paying taxes - before, during, and after the transition. International Journal of Social Economics, 33(12), 832-857. https://doi.org/10.1108/03068290610714670

Alm, J., \& Torgler, B. (2006). Culture differences and tax morale in the United States and in Europe. Journal of Economic Psychology, 27, 224-246. https://doi.org/10.1016/j.joep.2005.09.002

Barone, G., \& Mocetti, S. (2011). Tax morale and public spending inefficiency. International Tax and Public Finance, 18(6), 724-749. https://doi.org/10.1007/s10797-011-9174-z

Bernasconi, M., Corazzini, L., \& Seri, R. (2014). Reference dependent preferences, hedonic adaptation and tax evasion: Does the tax burden matter?. Journal of Economic Psychology, 40, 103-118. https://doi.org/10.1016/j.joep.2013.01.005

Bobek, D.D., \& Hatfield, R.C. (2003). An Investigation of the Theory of Planned Behavior and the Role of Moral Obligation in Tax Compliance. Behavioral Research In Accounting, 15, 13-38. 
http://dx.doi.org/10.2308/bria.2003.15.1.13

Bobek, D.D., Roberts, R.W., \& Sweeney, J.T. (2007). The social norms of tax compliance: Evidence from Australia, Singapore, and the United States. Journal of Business Ethics, 74(1), 49-64. https://doi.org/10.1007/s10551-006-9219-x

Buehn, A., \& Schneider, F. (2012). Shadow Economies in highly developed OECD countries: What are the driving forces? (IZA Discussion Paper No. 6891, Institute of Labor Ecnomics). Retrieved from http://ideas.repec.org/p/jku/econwp/2013_17.html on November 11, 2019.

Central Statistical Office (GUS). (2018). Działalność przedsiębiorstw niefinansowych w $2017 \mathrm{r}$. (Activity of nonfinancial enterprises in 2017). Warsaw.

Doerrenberg, P., \& Peichl, A. (2013). Progressive taxation and tax morale. Public Choice, 155(3-4), 293-316. https://doi.org/10.1007/s11127-011-9848-1

Enste, D.H. (2010). Regulation and shadow economy: empirical evidence for 25 OECD-countries. Constitutional Political Economy, 21, 231-248. https://doi.org/10.1007/s10602-009-9081-9

Ferrer-i-Carbonell, A., \& Gërxhani, K. (2016). Tax evasion and well-being: A study of the social and institutional context in Central and Eastern Europe. European Journal of Political Economy, 45, 149-159. https://doi.org/10.1016/j.ejpoleco.2016.09.004

Gërxhani, K. (2007). "Did you pay your taxes?" How (not) to conduct tax evasion surveys in transition countries. Social Indicators Research, 80(3), 555-581. https://doi.org/10.1007/s11205-006-0007-x

Ghosh, D., \& Crain, T.L. (1996). Experimental Investigation of Ethical Standards and Perceived Probability of Audit on Intentional Noncompliance. Behavioral Research in Accounting, 8, 219-244.

Hanousek, J., \& Palda, F. (2004). Quality of government services and the civic duty to pay taxes in the Czech and Slovak Republics, and other transition countries. Kyklos, 57(2), 237-252. https://doi.org/10.1111/j.0023-5962.2004.00252.x

Henderson, B.C., \& Kaplan, S.E. (2005). An Examination of the Role of Ethics in Tax Compliance Decisions. The Journal of the American Taxation Association, 27(1), 39-72. https://doi.org/10.2308/jata.2005.27.1.39

James, S., Mcgee, R.W., Benk, S., \& Budak, T. (2019). How seriously do taxpayers regard tax evasion? A survey of opinion in England. Journal of Money Laundering Control, 22(3), 563-575. https://doi.org/10.1108/JMLC-09-2018-0056

Joulfaian, D. (2009). Bribes and business tax evasion. European Journal of Comparative Economics, $6(2), 227-244$.

Kaplan, S.E., Newberry, K.J., \& Reckers, P.M.J. (1997). The Effect of Moral Reasoning and Educational Communications on Tax Evasion Intentions. Journal of the American Taxation Association, 19(2), 38-54.

Kogler, C., Batrancea, L., Nichita, A., Pantya, J., Belianin, A., \& Kirchler, E. (2013). Trust and power as determinants of tax compliance: Testing the assumptions of the slippery slope framework in Austria, Hungary, Romania and Russia. Journal of Economic Psychology, 34, 169-180. https://doi.org/10.1016/j.joep.2012.09.010

Lisi, G. (2015). Tax morale, tax compliance and the optimal tax policy. Economic Analysis and Policy, 45, 27-32. https://doi.org/10.1016/j.eap.2014.12.004

Luttmer, E.F.P., \& Singhal, M. (2014). Tax Morale. Journal of Economic Perspectives, 28(4), 149-168. https://doi.org/10.1257/jep.28.4.149

Mcgee, R.W., \& Benk, S. (2019). Christian attitudes toward ethics of tax evasion: a case study. Journal of Financial Crime, 26(1), 74-94. https://doi.org/10.1108/JFC-11-2017-0104

McGee, R.W., \& Benk, S. (2011). The ethics of tax evasion: A study of Turkish opinion. Journal of Balkan and Near Eastern Studies, 13(2), 249-262. https://doi.org/10.1080/19448953.2011.578869 
Nur-Tegin, K.D. (2008). Determinants of business tax compliance. B E Journal of Economic Analysis \& Policy, 8(1), 28. https://doi.org/10.2202/1935-1682.1683

Pickhardt, M., \& Prinz, A. (2014). Behavioral dynamics of tax evasion - A survey. Journal of Economic Psychology, 40, 1-19. https://doi.org/10.1016/j.joep.2013.08.006

Putniňš, T.J., \& Sauka, A. (2015). Measuring the shadow economy using company managers. Journal of Comparative Economics, 43(2), 471-490. https://doi.org/10.1016/j.jce.2014.04.001

Russo, F.F. (2013). Tax morale and tax evasion reports. Economics Letters, 121(1), 110-114. https://doi.org/10.1016/j.econlet.2013.07.004

Schneider, F. (2014). Work in the Shadow: Micro and Macro Results. International Economic Journal, 28(3), 365-379. https://doi.org/10.1080/10168737.2014.936924

Slemrod, J. (2007). Cheating Ourselves: The Economics of Tax Evasion. Journal of Economic Perspectives, 21(1), 25-48. https://doi.org/10.1257/jep.21.1.25

Torgler, B. (2005). Tax morale in Latin America. Public Choice, 122(1-2), 133-157. https://doi.org/10.1007/s11127-005-5790-4

Torgler, B., \& Schneider, F. (2007). Shadow Economy, Tax Morale, Governance and Institutional Quality: A Panel Analysis (IZA Discussion Paper No. 2563, Institute of Labor Ecnomics). Retrieved from http://ftp.iza.org/dp2563.pdf on 11 November, 2019.

Torgler, B., \& Schneider, F. (2009). The impact of tax morale and institutional quality on the shadow economy. Journal of Economic Psychology, 30(2), 228-245. https://doi.org/10.1016/j.joep.2008.08.004

van Dijke, M., \& Verboon, P. (2010). Trust in authorities as a boundary condition to procedural fairness effects on tax compliance. Journal of Economic Psychology, 31(1), 80-91. https://doi.org/10.1016/j.joep.2009.10.005

Webley, P., Cole, M., \& Eidjar, O.P. (2001). The prediction of self-reported and hypothetical tax-evasion: Evidence from England, France and Norway. Journal of Economic Psychology, 22(2), 141-155.

Wenzel, M. (2004). An analysis of norm processes in tax compliance. Journal of Economic Psychology, 25(2), 213-228. https://doi.org/10.1016/S0167-4870(02)00168-X

Wenzel, M. (2005). Motivation or rationalisation? Causal relations between ethics, norms and tax compliance. Journal of Economic Psychology, 26(4), 491-508. https://doi.org/10.1016/j.joep.2004.03.003 


\section{Appendix A: Description of the sample}

Table A1. The number of companies according to employment level

\begin{tabular}{|c|c|c|c|}
\hline Employment level & $\begin{array}{c}\text { No. of companies } \\
\text { in the sample }\end{array}$ & $\begin{array}{c}\text { Share in the total } \\
\text { sample (\%) }\end{array}$ & $\begin{array}{c}\text { Enterprises by size class } \\
\text { in Poland (2017)* (\%) }\end{array}$ \\
\hline $0-9$ & 438 & 96.48 & 96.5 \\
\hline $10-49$ & 15 & 3.3 & 2.59 \\
\hline $50-249$ & 1 & 0.22 & 0.74 \\
\hline
\end{tabular}

*Based on Statistics Poland (2018) data; share in the total number of non-financial enterprises.

Source: own elaboration based on company survey study.

Table A2. The number of companies according to economic sector

\begin{tabular}{|l|c|}
\hline \multicolumn{1}{|c|}{ Sector } & No. of companies in the sample \\
\hline Manufacturing & 85 \\
\hline Wholesale & 35 \\
\hline Retail & 57 \\
\hline Services & 228 \\
\hline Construction & 49 \\
\hline
\end{tabular}

Source: own elaboration based on the company survey.

Table A3. The number of companies per region

\begin{tabular}{|l|c|}
\hline \multicolumn{1}{|c|}{ Region (voivodship) } & No. of companies in the sample \\
\hline Lower Silesia & 38 \\
\hline Kujawy-Pomerania & 31 \\
\hline Lublin & 19 \\
\hline Lubuskie & 13 \\
\hline Lodz & 34 \\
\hline Malopolska & 41 \\
\hline Mazovia & 79 \\
\hline Opole & 14 \\
\hline Podkarpacie & 18 \\
\hline Podlasie & 2 \\
\hline Pomerania & 16 \\
\hline Silesia & 50 \\
\hline Swietokrzyskie & 12 \\
\hline Warmia-Masuria & 15 \\
\hline Wielkopolska & 47 \\
\hline West Pomerania & 25 \\
\hline Source: own &
\end{tabular}

Source: own elaboration based on the company survey. 
Appendix B: Questionnaire form (selected questions used on the model)

\begin{tabular}{|c|c|c|c|}
\hline Question & Answers options & $\begin{array}{c}\text { Variable } \\
\text { name }\end{array}$ & $\begin{array}{l}\text { Variable } \\
\text { type/Link- } \\
\text { ing with the } \\
\text { hypothesis }\end{array}$ \\
\hline $\begin{array}{l}\text { Please estimate the degree of underre- } \\
\text { porting business income (in \%) by firms } \\
\text { in your industry in } 2016 .\end{array}$ & Exact number & $\begin{array}{l}\text { underre- } \\
\text { port_in- } \\
\text { come_2016 }\end{array}$ & $\begin{array}{l}\text { Dependent } \\
\text { variable }\end{array}$ \\
\hline $\begin{array}{l}\text { Companies in your industry would think it } \\
\text { is always justified to cheat on tax if they } \\
\text { have the chance. }\end{array}$ & $\begin{array}{l}\text { 1: strongly disagree, } 2: \text { disa- } \\
\text { gree, } 3: \text { neither agree nor } \\
\text { disagree, } 4: \text { agree } 5: \\
\text { strongly agree }\end{array}$ & $\begin{array}{l}\text { justi- } \\
\text { fied_to_che } \\
\text { at }\end{array}$ & $\begin{array}{l}\text { H1 (tax mo- } \\
\text { rale) }\end{array}$ \\
\hline $\begin{array}{l}\text { As I list some factors that can affect the } \\
\text { current operations of a business, please } \\
\text { tell me if you think that each factor is No } \\
\text { Obstacle, a Minor Obstacle, a Moderate } \\
\text { Obstacle, a Major Obstacle, or a Very Se- } \\
\text { vere Obstacle to the current operations } \\
\text { of this establishment; factor in trade and } \\
\text { customs regulation. }\end{array}$ & $\begin{array}{l}\text { 0: no obstacle; } 1 \text { : minor, } 2: \\
\text { moderate, } 3 \text { : major, } 4 \text { : very } \\
\text { severe obstacle }\end{array}$ & $\begin{array}{l}\text { obsta- } \\
\text { cle_trade }\end{array}$ & $\begin{array}{l}\mathrm{H} 2 \text { (regula- } \\
\text { tions) }\end{array}$ \\
\hline $\begin{array}{l}\text { Please evaluate your satisfaction with the } \\
\text { performance of the state revenue service } \\
\text { with regards to tax administration. }\end{array}$ & $\begin{array}{l}\text { 1: very unsatisfied, } 2 \text { : Unsat- } \\
\text { isfied, } 3 \text { : Neither satisfied } \\
\text { nor unsatisfied, } 4: \text { Satisfied, } \\
\text { 5: very satisfied }\end{array}$ & $\begin{array}{l}\text { tax_admin- } \\
\text { istration_sat }\end{array}$ & $\begin{array}{l}\text { H3: (govern- } \\
\text { ance qual- } \\
\text { ity) }\end{array}$ \\
\hline $\begin{array}{l}\text { As I list some factors that can affect the } \\
\text { current operations of a business, please } \\
\text { tell me if you think that each factor is No } \\
\text { Obstacle, a Minor Obstacle, a Moderate } \\
\text { Obstacle, a Major Obstacle, or a Very Se- } \\
\text { vere Obstacle to the current operations } \\
\text { of this establishment; factor in tax rates. }\end{array}$ & $\begin{array}{l}\text { 0: no obstacle; } 1 \text { : minor, } 2 \text { : } \\
\text { moderate, } 3 \text { : major, } 4 \text { : very } \\
\text { severe obstacle }\end{array}$ & $\begin{array}{l}\text { obsta- } \\
\text { cle_tax_rate } \\
\text { s }\end{array}$ & $\begin{array}{l}\text { Control var- } \\
\text { iable }\end{array}$ \\
\hline $\begin{array}{l}\text { Approximately how many employees are } \\
\text { currently employed in your company } \\
\text { (full-time equivalent, including you)? }\end{array}$ & $\begin{array}{l}\text { 1: } 1-5 \text { employees; } 2: 6-10 \\
\text { employees; } 3: 11-20 \text { em- } \\
\text { ployees; } 4: \text { 21-40 employ- } \\
\text { ees; } 5: \text { 41-60 employees; } 6: \\
\text { 61-100 employees; 7: } 101- \\
\text { 150 employees }\end{array}$ & $\begin{array}{l}\text { no_employ- } \\
\text { ees }\end{array}$ & $\begin{array}{l}\text { Control var- } \\
\text { iable }\end{array}$ \\
\hline $\begin{array}{l}\text { What is the main activity (i.e. sector) that } \\
\text { your company is engaged in? }\end{array}$ & $\begin{array}{l}\text { 1: manufacturing; } 2 \text { : whole- } \\
\text { sale, } 3 \text { : retail, } 4: \text { services, } 5: \\
\text { construction, } 6: \text { other }\end{array}$ & sector & $\begin{array}{l}\text { Control var- } \\
\text { iable }\end{array}$ \\
\hline
\end{tabular}

Source: own elaboration based on company survey study. 


\section{Author}

\section{Dagmara Nikulin}

Assistant Professor at the Gdansk University of Technology, Faculty of Management and Economics. She received her MSc degree in Economics (the Poznań University of Economics and Business) and BA in Philosophy (the Adam Mickiewicz University in Poznań). She received her PhD from the Gdansk University of Technology in 2014. In 2016, she was visiting researcher at the University of Glasgow (Dekaban Liddle Fellowship Award). Her research interests focus on labour economics, informal employment, and international economics.

Correspondence to: Dagmara Nikulin, PhD, Assistant Professor, Gdansk University of Technology, Faculty of Management and Economics, Narutowicza 11/12, 80-233 Gdansk, Poland, e-mail: dagkowal@pg.edu.pl

ORCID (1) http://orcid.org/0000-0002-0534-4553

\section{Acknowledgements and Financial Disclosure}

The article came into being within the project financed by the National Science Centre, Poland (Narodowe Centrum Nauki-NCN) - decision number DEC-2015/19/B/HS4/02884.

\section{Copyright and License}

(c) (1) $\Theta$

This article is published under the terms of the Creative Commons

Attribution - NoDerivs (CC BY-ND 4.0) License http://creativecommons.org/licenses/by-nd/4.0/

Published by the Centre for Strategic and International Entrepreneurship - Krakow, Poland 
